\title{
Meningkatan Hasil Belajar Pendidikan Jasmani Olahraga dan Kesehatan Materi Permainan Kasti Melalui Pendekatan Bermain
}

\author{
I Nyoman Sumarta*
}

Sekolah Dasar Negeri 3 Mengwi

A R T I C L E I N F O

Article history:

Received 20 May 2019

Received in revised form 10 June 2019

Accepted 30 July 2019

Available online 28

August 2019

Kata Kunci:

Hasil Belajar, Pendekatan

Bermain, Permaianan

Kasti..

Keywords:

Learning Outcomes, Play

Approach, Game Study.

\begin{abstract}
A B S T RA K
Prasarana pembelajaran telah memenuhi kebutuhan pelaksanaan pembelajaran PJOK, namun yang menjadi ganjalan bagi Peneliti adalah belum tercapainya hasil belajar PJOK bagi siswa kelas IV SD Negeri 3 Mengwi sesuai dengan harapan Peneliti. Hasil tes Prasiklus menunjukkan bahwa nilai rata-rata yang dicapai siswa pada semester ganjil tahun pelajaran 2016/2017 adalah 73 dan ketuntasan belajar mencapai $45,2 \%$. Rendahnya hasil belajar yang dicapai siswa kelas IV SD Negeri 3 Mengwi adalah kurang semangatnya anak-anak dalam mengikuti pembelajaran PJOK dan kondisi fisik siswa SD belum kuat menunjang aktivitas kegiatan PJOK. Melihat kondisi tersebut Peneliti terdorong untuk melakukan perbaikan - perbaikan melalui Penelitian Tindakan Kelas melalui pendekatan bermaindalam pembelajaran PJOK dengan mengangkat materi Permainan kasti. Tujuan dari penelitian ini adalah untuk meningkatkan hasil belajar PJOK melalui pendekatan bermain bagi siswa kelas IV SD Negeri 3 Mengwi . Penelitian inii dilakukan dalam 2 siklus dengan langkah-langkah yaitu : (1). Perencanaan, (2). Pelaksanaan, (3). observasi, (4). Refleksi/Tindakan. Hasil penelitiannya adalah: hasi lbelajar padasiklus I nilai rata-rata menunjukkan 79,3 sedangkan hasil belajar pada siklus II nilai rata-rata
\end{abstract} 83,0. Berdasarkan data penelitian dan pembahasan dapat diambil kesimpulan bahwa dengan pendekatan bermain dalam pembelajaran PJOK dapat meningkatkan hasil belajar siswa kelas IV SD Negeri 3 Mengwi dengan baik..

A B S T R A C T

Learning infrastructure has fulfilled the needs of PJOK learning, but what has become a problem for researchers is the lack of achievement of PJOK learning outcomes for fourth grade students of SD Negeri 3 Mengwi in accordance with Researcher's expectations. The Prasiklus test results showed that the average score achieved by students in the odd semester of 2016/2017 academic year was 73 and learning completeness reached 45.2\%. The low learning outcomes achieved by Grade IV students of SD Negeri 3 Mengwi are the lack of enthusiasm of children in participating in PJOK learning and the physical condition of elementary students is not yet strong enough to support the activities of PJOK. Seeing these conditions Researchers are encouraged to make improvements through Classroom Action Research through a play approach in PJOK learning by raising the game's material. The purpose of this study was to improve the learning outcomes of PJOK through a play approach for fourth grade students of SD Negeri 3 Mengwi. This research was conducted in 2 cycles with steps namely: (1). Planning, (2). Implementation, (3). observation, (4). Reflection / Action. The results of the study were: learning outcomes in the first cycle the average value showed 79.3 while the learning outcomes in the second cycle had an average value of 83.0. Based on research data and discussion it can be concluded that the approach to play in learning PJOK can improve learning outcomes of fourth grade students of SD Negeri 3 Mengwi well. 


\section{Pendahuluan}

Pendidikan jasmani merupakan mata pelajaran yang berkaitan dengan kebugaran jasmani baik di SD, SMP, maupun SMA (Sulistiono, 2014). Pendidikan jasmani pada dasarnya merupakan bagian integral dari sistem pendidikan secara keseluruhan yang bertujuan untuk mengembangkan aspek kesehatan. Aktivitas jasmani diartikan sebagai kegiatan peserta didik untuk meningkatkan keterampilan motorik dan nilai-nilai fungsional yang mencakup kognitif, afektif dan sosial, sehingga melalui kegiatan pendidikan jasmani diharapkan anak didik. dapat tumbuh dan berkembang sehat dan segar jasmaninya, serta perkembangan pribadinya secara harmonis (Firmansyah, 2009).Pendidikan jasmani merupakan alat untuk mencapai keterlaksanaan pembelajran mata pelajaran Pendidikan Jasmani dan Olah raga di sekolah sebelum mendapatkan format yang tepat, karena selalu menyesuaikan perubahan kurikulum (Utama, 2011). Pendidikan jasmani merupakan salah satu kelompok mata pelajaran yang lebih menekankan kepada peningkatan fi sik, sportivitas, disiplin, kerjasama, dan kesadaran hidup sehat (Yudiana, 2015). Pada kurikulum yang berlaku saat ini diharapkan dapat menggali potensi yang ada pada anak untuk dikembangkan lebih lanjut agar potensi mereka dapat terbina dan tersalurkan berdasarkan karakteristik siswa (Pramono, 2012). Namun demikian hasil secara nyata dalam kurun waktu yang telah ditentukan belum bisa dilihat secara nyata, hanya sebagian kecil siswa yang mempunyai potensi bagus dapat mengikuti alurnya dan ini berkembang melalui jalur ekstra atas dukungan semangat orang tua siswa.

Dalam proses pembelajaran Pendidikan Jasmani, guru diharapkan mengajarkan berbagai ketrampilan gerak dasar, teknik dan strategi permainan dan olahraga, internalisasi nilai-nilai (sportifitas, jujur, kerjasama, dan lain-lain) serta pembiasaan hidup sehat. Dalam pelaksanaan pembelajaran guru dapat memberikan berbagai pendekatan agar siswa termotivasi dan tertarik untuk mengikuti pembelajaran. Cara pelaksanaan pembelajaran kegiatan dapat dilakukan dengan latihan, menirukan, permainan, perlombaan, dan pertandingan (Depdiknas, 2003:5-6).

Keadaan siswa SD Negeri 3 Mengwi pada dasarnya senang terhadap pembelajaran pendidikan jasmani dan olah raga, terutama pada permainan kasti. Namun suatu hal yang membuat belum tercapainya hasil belajar yang standar dalam mata pelajaran PJOK adalah belum maksimalnya kemampuan fisik siswa dalam menunjang aktivitas kegiatan pembelajaran PJOK sehingga gerak-gerak dasar dalam permainan kasti seperti dalam melakukan pukulan bola, mengayunkan pemukul dengan tepat, menangkap bola, kemampuan siswa masih kurang. Kondisi demikian berdampak terhadap nilai yang dicapai siswa belum maksimal.

Berdasarkan uraian diatas, maka perlu dilakukan suatu langkah tepat untuk meningkatkan hasil belajar siswa pada mata pelajaran PJOK terutama pada materipermainan kasti. Salah satu upaya yang dilakukan oleh Peneliti adalah melakukan Penelitian Tindakan Kelas yang bertujuan untuk meningkatkan hasil belajar siswa dalam pelajaran PJOK. Dalam penelitian ini materi yang dipilih adalah permaian kasti sesuai yang Peneliti ajarkan, sehingga secara keseluruhan judul yang Peneliti pilih adalah, 'Meningkatan Hasil Belajar pendidikan Jasmani Olahraga Dan Kesehatan Materi Permainan Kasti Melalui Pendekatan Bermain Bagi Siswa Kelas IV SD Negeri 3 Mengwi Tahun Pelajaran 2016/2017".

Tujuan penelitian ini adalah sebagai berikut: 1. Untuk mengetahui apakah dengan menerapakan pendekatan bermain dapat meningkatan hasil pembelajaran Pendidikan jasmani Olahraga Dan Kesehatan SD Negeri 3 Mengwi tahun pelajaran 2016/2017, dan 2. Untuk mengetahui seberapa besar peningkatan hasil belajar Pendidikan Jasmani Olahraga Dan Kesehatan SD Negeri 3 Mengwi tahun pelajara 2016/2017 dengan diterapkanyapendekatan bermain..

\section{Metode}

Untuk memperoleh hasil yang logis dan signifikan dalam Penelitian Tindakan Kelas ini, maka metode yang digunakan dalam pengolahan hasil penelitian ini adalah deskriptif analitis, yaitu studi yang digunakan untuk mengumpulkan data, mendeskripsikan, mengolah, menganalisa, menafsirkan dan menyimpulkan data penelitian sehingga diperoleh gambaran yang sistematis. Hasil analisis ini dijadikan bahan dalam penulisan laporan.

Penelitian ini dilakukan di KelasIV SD Negeri 3 Mengwi pada Semester Ganjil tahun pelajaran 2016/2017, karena kelas ini adalah kelas yang nilai Pendidikan Jasmani Olahraga dan Kesehatannya belum mencapai diatas Rata-rata kelas, atau masih rendah. Disamping itu peneliti juga guru Penjaskes di SD Negeri 3 Mengwi. Subjek penelitian sebanyak 31orang yang terdiri dari 18 0rang siswa perempuan dan 13 orang siswa laki-laki. Kelas itu dijadikan sebagai subjek penelitian karena rata-rata hasil tes awal (pra siklus) dengan nilai rata-rata 73 dan ketuntasan belajar mencapai 45,2\%, sehingga perlu segera ditangani. 
Waktu Penelitian mulai dari Perencanaan sampai dengan penulisan laporan hasil penelitian tersebut mulai dari bulan Agustuss.d Desember 2016. Karena pada bulan Agustus adalah awal tahun ajaran baru dimulai dan kegiatan serta aktivitas belajar yang sangat tepat bagi Peneliti untuk melakukan Penelitian Tindakan Kelas terutama untuk aktivitas Pendidikan Jasmani Olahraga dan Kesehatan. Maka Peneliti memanfaatkan waktu ini secara efektif. Pelaksanaan Penelitian Tindakan Kelas mengacu pada kalender Pendidikan yang ditetapkan oleh sekolah.

Pelaksananaan Penelitian Tindakan Kelas ini terdiri dari dua siklus, dimana setiap siklus terdiri dari empat komponen yaitu :

1. Tahap Perencanaan (Planning)

Pada tahap ini Peneliti menyusun Rencana Pembelajaran (RP), materi pokok pada mata pelajaran Pendidikan Jasmani Olahraga dan Kesehatan yang akan diajarkan kepada siswa bersama dengan Indikatornya.

Pelaksanaan Pada siklus I, II, di rencanakan dalam persiapan ini. Selanjutnya dilakukan pemilihan masalah yang potensial diangkat dalam penelitian ini atau sesuai judul yang telah disetujui dalam proposal Penelitian Tindakan Kelas ini.

Pelaksanaan Studi Pendahuluan, melakukan perumusan masalah, memilih pendekatan yang akan diterapkan dalam penelitian ini, kemudian menentukan variabel dan menentukan sumber data. Mempersiapkan alat dan bahan adalah hal penting dalam penelitian ini, dan penyusunan instrumen tes uji kompetensi serta lembar observasi. Terkait dengan peningkatan kemampuan siswa dalam menganalisis laporan dan menanggapi isi laporan pada pelajaran Pendidikan Jasmani Olahraga dan Kesehatanmelalui penerapan metoda pembelajaranbermain, maka persiapan kepada siswa diharapkan agar dapat berkosentrasi serta memusatkan perhatiannya untuk mengikuti kegiatan belajar dengan baik.

2. Pelaksanaan tindakan (Acting),

Kegiatan yang dilakukan pada tahap ini adalah melaksanakan pembelajaran sebagaimana scenario pembelajaran yang telah ditetapkan pada RPP.

3. Pengamatan (Observasi).

Pada tahap ini dilakukan proses observasi terhadap pelaksanaan tindakan dengan menggunakan lembar observasi yang telah dibuat.

4. Refleksi (Refleting)

Setiap siklus saling berkaitan dan berhubungan, karena hasil refleksi akan digunakan sebagai acuan untuk perbaikan pada siklus berikutnya. Diharapkan setiap siklus ada peningkatan yang signifikan mengenai pembelajaran Pendidikan Jasmani Olahraga dan Kesehatan dengan kemampuanmeningkatkan hasil belajar PJOK, untuk meningkatkan mutu poembelajaran sehingga hasil belajar siswa dapat ditingkatkan sesuai tujuan pembelajaran.Peneliti mengadakan perubahan dan peningkatan dalam pelaksanaan pembelajaran di setiap siklus. Dengan melihat perubahan sikap siswa sehingga peningkatan hasil belajar mata pelajaran PJOK siswa dapat terobservasi perkembangannya di setiap siklus.

Pelaksanaan penelitian dilaksanakan dengan mengambil data dan informasi tentang pelaksanaan pembelajaran dan hasil belajar siswa terhadap mata pelajara Pendidikan Jasmani Olahraga dan Kesehatan dengan materi permainan kasti dengan menerapkan pendekatan bermain yang telah ditetapkan dalam penelitian ini. Pembelajaran dilaksanakan sesuai dengan rencana yang telah dirancang untuk Penelitian ini. Hasil yang didapat pada tahap observasi kemudian dianalisis bersama-sama antara peneliti dengan observer. Dengan berpatokan pada hasil analisis tersebut, guru dapat merencanakan tindak lanjut pada siklus berikutnya. Observasi dilaksanakan pada saat pembelajaran berlangsung. Dalam observasi yang diamati adalah kegiatan guru dan aktivitas siswa dalam mengikuti pelajaran Pendidikan Jasmani Olahraga dan Kesehatan.

Observasi dilaksanakan oleh peneliti dan bekerja sama dengan teman sejawat (guru mata pelajaran lain) dari kelas lain di SD Negeri 3 Mengwi. Dengan menggunakan instreumen observasi yang telah disiapkan baik instrumen untuk guru dan instrumen untuk mengamati kegiatan belajar siswa, dilakukan pengamatan secara langsung oleh observer. Hasil yang di peroleh dalam observasi ini dijadikan acuan dalam melakukan pembahasan terhadap kelemahan -kelemahan yang terjadi selama kegiatan pembelajaran berlangsung.

Analisis data menggunakan teknik kuantitatif berupa perhitungan dan teknik kualitatif berupa uraian. Setelah data terkumpul dan diperiksa, bila memenuhi persyaratan, maka data tersebut diolah dan dihitung presentasenya. Sedangkan langkah-langkahnya adalah sebagai berikut: 1.Mengumpulkan data, 2 . Menyeleksi data, 3. Mengklarifikasi data, dan 4. Menghitung prosentase

Data dari hasil Penelitian secara sistematis dan kemudian ditarik suatu kesimpulan umum, baik secara narasi maupun dalam bentuk grafik. Indikator kinerja dibutuhkan dalam penelitian agar pelaksanaannya dapat mendatangkan hasil yang positif dan sesuai dengan apa yang dikehendaki yaitu meningkatnya hasil belajar siswa kelas IV SD Negeri 3 Mengwi terhadap pembelajaran Pendidikan 
Jasmani Olahraga dan Kesehatan dan pemahaman siswa terhadaptswknik dasar gerak permainan kasti bisa lebih baik. Di harapkan dalam penelitian inii terdapat peningkatan hasil yang signifikan diperoleh dari setiap siklus, sehingga akan berdampak pada peningkatan kemampuan siswa untuk melakukan pelajaran Pendidikan Jasmani Olahraga dan Kesehatan di kelas IV SD Negeri 3 Mengwi .

Hasil akhir yang diperoleh adalah meningkatnya nilai akademis siswa pada mata pelajaran Pendidikan Jasmani Olahraga dan Kesehatan menjadi lebih baik dan menjadi lebih menarik serta menyenangkan bagi siswa. Penelitian Tindakan Kelas bertujuan untuk mengukur sejauh mana aktifitas siswa dalam proses KBM permainan kasti untuk mengukur tingkat kepuasan siswa dalam proses KBM dengan pendekatan bermain pada siswa SD Nrgri 3 Mengwi bagi keals IV. Untuk melihat hasil belajar dari sebuah proses pembelajaran dapat dilihat dari pencapaian hasil pembelajaran yang sudah dilaksanakan dengan hasil dari pembelajaran melalui pendekatan bermain yaitu $80 \%$ dapat dikatakn tuntas.

\section{Hasil dan Pembahasan}

Hasil pra siklus yang dilakukan pada penelitian ini dapat di uraikan beberapa hal sebagai berikut.

Sebanyak 14 orang siswa yang mendapat nilai rata-rata diatas KKM dengan katagori tuntas dalam mencapai hasil belajar mata pelajaran Pendidikan Olahraga dan Kesehatan dengan materi Permainan Kasti. Sebanyak17 orang siswa yang mendapat nilai rata-rata dibawah KKM dengan kata gori belum tuntas. Nilai Rata-rata yang dicapai pada prasiklus 73, Ketercapaian ketuntasan belajar siswa mencapai $45,2 \%$, dan siswa yang belum tuntas adalah : $54,8 \%$

Dari hasil pengamatan Peneliti pada prasiklus ini ditemukan atau di ungkap permasalahanpermasalahan yang ada pada siswa kelas IV SD Negeri 3 Mengwi terhadap pembelajaran Pendidikan Jasmani Olahraga dan Kesehatan pada genap Tahun Pelajaran 2016/2017 yakni :

Siswa kelas IV SD kekuatan fisiknya belum baik sehingga belum kuat dalam menopang kegiatan teknik dasar permainan kasti. Belum diterapkannya metoda dengan npendekatan yang relevan dalam pembelajaran PJOK bagi siswa kelas IV SD. Kemampuan dalam menyimak konsep materi pengetahuan belum baik sehingga hasil belajar yang dicapai pada prasiklus rendah.,

Belum terciptanya suasana belajar yang menyenangkan dalam pembelajaran PJOK. Siswa perlu bimbingan dan motivasi agar belajar lebih semangat dan bisa menyenangkan. Berdasarkan permasalahan tersebut diatas, perlu dilakukan perbaikan dan melalui Penelitian Tindakan Kelas ini. Peneliti akan melakukan perbaikan dari siklus, persiklus dengan melaksanakan tindakan refleksi bagi siswa yang belum mencapai nilai standar KKM/belum tuntas dengan menerapkan metoda belajar dengan pendekatan bermain secara konsisten. Hasil refleksi yang telah dicapai pada siklus I dapat disajikan dalam bentuk Tabel 1 berikut

Tabel 1. Rangkuman Rekapitulasi Hasil Siswa Siklus I

\begin{tabular}{lcccccccc}
\hline No & $\begin{array}{c}\text { Jumlah } \\
\text { siswa }\end{array}$ & $\begin{array}{c}\text { Nilai } \\
\text { tertinggi }\end{array}$ & $\begin{array}{c}\text { Nilai } \\
\text { terendah }\end{array}$ & $\begin{array}{c}\text { Nilai } \\
\text { rata- } \\
\text { rata } \\
\text { kelas }\end{array}$ & Jumlah & $\begin{array}{c}\text { Sersen } \\
(\%)\end{array}$ & Jumlah & $\begin{array}{c}\text { Siswa yang belum } \\
\text { tuntas } \\
(\%)\end{array}$ \\
\hline 1 & 31 & 86 & 70 & 79,3 & 27 & $87,1 \%$ & 4 & $12,9 \%$ \\
\hline
\end{tabular}

Dari hasil rekapitulasi tersebut diatas dapat dijabarkan beberapa hal sebagai berikut : 1 . Sebanyak 27 orang siswa kelas IV SD Negeri 3 Mengwi yang mendapat nilai rata-rata diatas KKM dengan katagori tuntas dalam mencapai peningkatan hasil belajar Pendidikan Jasmani Olahraga dan Kesehatan, 2. Sebanyak 4 orang siswa kelas IV SD Negeri 3 Mengwi yang mendapat nilai rata-rata dibawah KKM dengan kata gori belum tuntas dalam meningkatkan meningkatkan hasil belajar Pendidikan jasmani Olahraga dan Kesehatan, 3. Nilai Rata-rata adalah 79,3, 4. Ketercapaian ketuntasan belajar mencapai $87,1 \%$, dan 5 . Siswa yang belum Tuntas $12,9 \%$

Dari hasil pengamatan Peneliti pada siklus I ini ditemukan atau di ungkap beberapa hal yang ada pada siswa kelas yakni : 1 . Tingkat kemampuan siswa dalam melakukan teknik dasar gerakan bermain kasti telah terjadi peningkatan, 2. Siswa nampak mulai berani bergerak dan telah paham terhadap peraturan dalam bermain kasti, 3. Pembelajaran Pendidikan Jasmani Olahraga dan Kesehatan telah menjadi kesenangan siswa dengan metoda bermain. 4. Guru telah menggunakan metoda belajar bermain secara efektif dan berdampak terhadap hasil yang dicapai siswa, dan 5. Siswa masih memerlukan bimbingan atau tuntunan dalam belajar PJOK secara intensif, untuk mencapai hasil yang maksimal.

Hasil refleksi yang telah dicapai pada siklus II dapat disajikan dalam bentuk tabel 2 berikut. 
Tabel 2. Rangkuman Rekapitulasi Hasil Siswa Siklus II

\begin{tabular}{|c|c|c|c|c|c|c|c|c|}
\hline \multirow{2}{*}{ No } & \multirow{2}{*}{$\begin{array}{l}\text { Jumlah } \\
\text { siswa }\end{array}$} & \multirow{2}{*}{$\begin{array}{l}\text { Nilai } \\
\text { tertinggi }\end{array}$} & \multirow{2}{*}{$\begin{array}{l}\text { Nilai } \\
\text { terendah }\end{array}$} & \multirow{2}{*}{$\begin{array}{l}\text { Nilai rata- } \\
\text { rata kelas }\end{array}$} & \multicolumn{2}{|c|}{ Siswa yang tuntas } & \multicolumn{2}{|c|}{$\begin{array}{c}\text { Siswa yang belum } \\
\text { tuntas }\end{array}$} \\
\hline & & & & & Jumlah & $\begin{array}{c}\text { Persen } \\
(\%)\end{array}$ & Jumlah & $\begin{array}{c}\text { Persen } \\
(\%)\end{array}$ \\
\hline 1 & 31 & 90 & 79 & 83,0 & 31 & $100 \%$ & - & $0 \%$ \\
\hline
\end{tabular}

Dari hasil rekapitulasi tersebut diatas dapat dijabarkan beberapa hal sebagai berikut: 1 . Sebanyak 31 orang siswa kelas IV SD Negeri 3 Mengwi yang mendapat nilai rata-rata diatas KKM dengan katagori tuntas dalam mencapai peningkatan hasil belajar Pendidikan Jasmani Olahraga dan Kesehatan, 2. Sebanyak 31 orang siswa kelas IV SD Negeri 3 Mengwi yang telah menuntaskan pembelajaran Pendidikan jasmani Olahraga dan Kesehatan, 3. Nilai Rata-rata adalah 83,0, 4. Ketercapaian ketuntasan belajar mencapai 100\%, Dan 5 . Siswa yang belum Tuntas $0 \%$

Dari hasil pengamatan Peneliti pada siklus II ini ditemukan atau di ungkap beberapa hal yang ada pada siswa kelas yakni : 1 . Tingkat kemampuan siswa dalam melakukan teknik dasar gerakan bermain kasti telah terjadi peningkatan serta mampu bermain secara kelompok, 2. Siswa nampak mulai berani bergerak dan telah paham terhadap peraturan dalam bermain kasti. 3. Pembelajaran Pendidikan Jasmani Olahraga dan Kesehatan telah menjadi kesenangan siswa dengan metoda bermain, 4. Guru telah menggunakan metoda belajar bermain secara efektif dan berdampak terhadap hasil yang dicapai siswa, dan 5. Siswa telah memaksimalkan kemampuannya dalam meningkatkan hasil belajar Pendidikan Jasmani Olahraga dan Kesehatan.

Berdasarkan atas uraian yang telah dipaparkan diatas maka Penelitian Tindakan Kelas ini secara keseluruhan telah mencapai ketuntasan belajar. Hasil yang dicapai pada Prasiklus dan Siklus I dan siklus II dapat disajikan dalam bentuk grafik seperti dibawah ini gambar 1

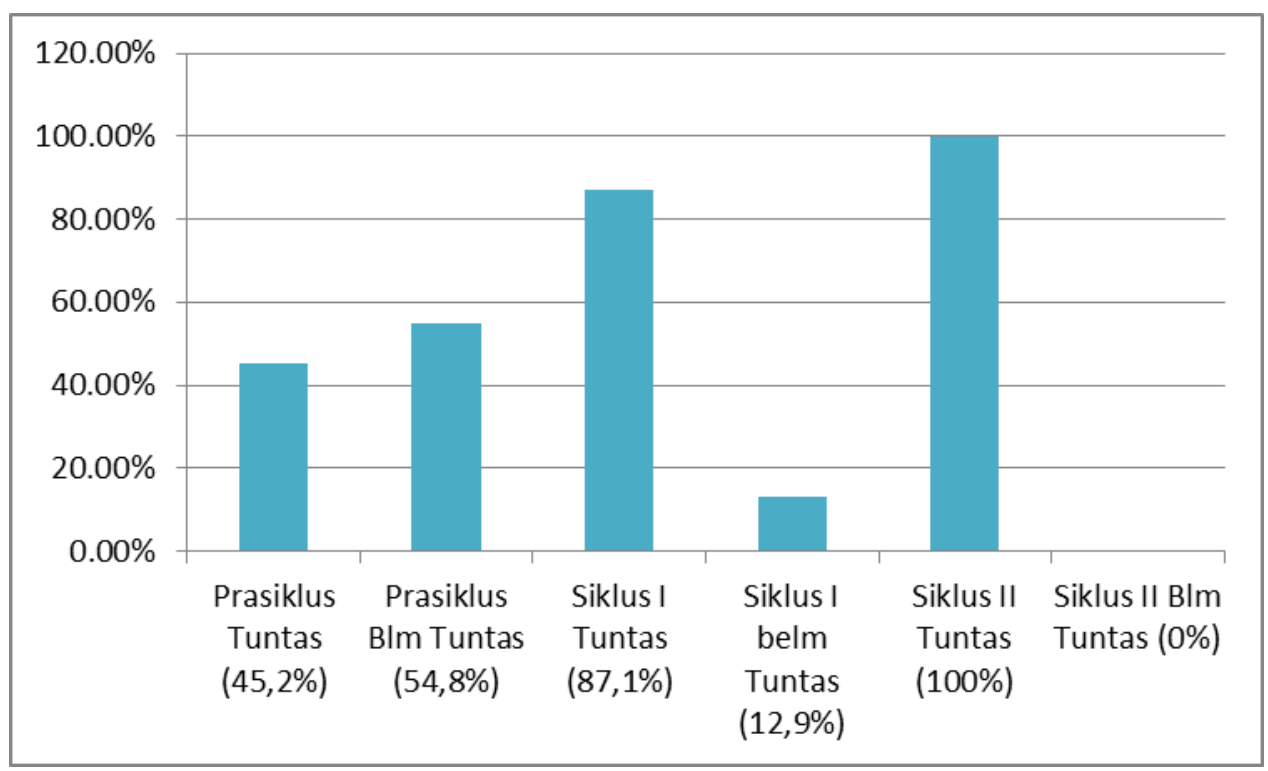

Gambar 1. Grafik Hasil yang dicapai pada Prasiklus dan Siklus I dan siklus II

Keterangan :

1. Ketuntasan belajar yang dicapai pada Prasiklus $\quad=45,2 \%$

2. Siswa yg belum tuntas pada Prasiklus $=54,8 \%$

3. Ketuntasan belajar yang dicapai pada siklus I $\quad=87,1 \%$

4. Siswa yang belum tuntas pada siklus I $\quad=12,9 \%$

5. Ketuntasan belajar yang dicapai pada siklus II $\quad=100 \%$

6. Siswa yang belum tuntas pada siklus II $\quad=0 \%$ 


\section{Simpulan Dan Saran}

Berdasarkan hasil analisis seperti yang sudah diuraikan, dapat disimpulkan bahwa dengan menerapkan pendekatan bermain hasil belajar siswa kelas IV SD Negeri 3 Mengwi tahun pelajaran 2016/2017 dapat meningkat. Peningkatan tersebut dapat dilihat dari hasil yang diperoleh pada prasiklus dengan nilai rata-rata 73,0 dan pada siklus I dengan nilai rata-rata 79,3 kemudian pada siklus II dengan nilai rata-rata 83,0. Dengan demikian terjadi peningkatan yang cukup signifikan.

Dengan demikian, jika hal ini dikaitkan dengan hipotesis tindakan yang berjudul "Meningkatkan Hasil Belajar Pendidikan Jasmani Olahraga Dan Kesehatan Dengan Menerapakan Pendekatan bermaian peran dalama Permaianan Kasti Siswa Kelas IV SD Negeri 3 Mengwi Tahun Pelajaran 2016/2017" diterima dan terbukti kebenarannya.

Setelah disimpulkan dari hasil penelitian ini, maka perlu kiranya dibuat saran-saran untuk menjadi perhatian dalam menetapkan kebijaksanaan yang berhubungan dengan mutu pembelajaran, khususnya mata pelajaran Penjaskes di SD Negeri 3 Mengwi. Saran-saran tersebut adalah sebagai berikut. 1. Bagi guru Penjaskes disarankan, bahwa proses pembelajaran dengan menggunakan pendekatan pembelajaran yang tepat bagi siswa SD dapat memotivasi siswa untuk melakukan aktivitas pembelajaran Penjaskes dengan baik dan tidak membosankan, menakutkan siswa dalam bergerak, 2. Metoda yang digunakan dalam pembelajaran Penjaskes perlu di pertimbangkan secara cermat bagi siswa SD karena usia anak SD masih muda dan belum mempunyai kekuatan pisik tinggi, 3. Jika guru memilih metoda pembelajaran yang sudah dianggap sesuai dapat digunakan sebagai alternatif dalam memilih dan menetapkan strategi atau metode pembelajaran, mata pelajaran penjaskes. Karena akan memberikan keuntungan diantaranya: dapat menciptakan suasana pembelajaran yang menyenangkan bagi siswa SD, tidak menjenuhkan siswa, tujuan pembelajaran dapat dicapai

\section{Daftar Rujukan}

Agus Budhi Juli ari, Paiman, Nuryono. 2009. Penjasorkes, untuk SD/MI, kelas IV. Pusat Perbukuan kementerian Pendidikan Nasional

Arikunto, Suharsimi, 2002. Prosedur Penelitian Suatu Pendekatan Praktik. Jakarta PT. Rineksa Cipta

Engkos S.R. 1994. Penjaskes. Jakarta; Erlangga

Firmansyah, H., 2009. Hubungan Motivasi Berprestasi Siswa dengan Hasil Belajar Pendidikan Jasmani. Jurnal Pendidikan Jasmani Indonesia, 6(1), pp.41-42.

Hadi, S., 2013. Survei Pendidikan Jasmani, Olahraga, dan Kesehatan pada Satuan Pendidikan SD, SMP, SMA Negeri se-Kecamatan Karangan Kabupaten Trenggalek. Jurnal Pendidikan Olahraga dan Kesehatan, $1(1)$.

Husni, Agusta, dkk. 1987. Buku Pintar Olahraga. Jakarta; CV Mawar Gempita

Pambudi, A.F., 2010. Target Games: Sebuah Pengembangan Konsep Diri Melalui Pembelajaran Pendidikan Jasmani. Jurnal Pendidikan Jasmani Indonesia, 7(2).

Pramono, H., 2012. Pengaruh sistem pembinaan, sarana prasarana dan pendidikan latihan terhadap kompetensi kinerja guru pendidikan jasmani sekolah dasar di kota Semarang. Jurnal Penelitian Pendidikan, 29(1).

Slamet, S.R. 1994. Penjaskes 3. Jakarta; Tiga Serangkai

Sukrisno,Aminarni, Suwarjo,Sri Sunarsih, Masri'an, Asy'ari. 2009. Pendidikan jasmani Olahraga dan Kesehatan untuk SD/MI kelas IV. Penerbit Erlangga.

Sulistiono, A.A., 2014. Kebugaran jasmani siswa pendidikan dasar dan menengah di Jawa Barat. Jurnal Pendidikan dan Kebudayaan, 20(2), pp.223-233. 
Tunjung sari. 2006. Buku penunjang Materi Penjaskes SD. Tri Agung

Utama, A.B., 2011. Pembentukan Karakter Anak Melalui Aktivitas BermainDalam Pendidikan Jasmani. Jurnal Pendidikan Jasmani Indonesia, 8(1).

Yudiana, Y., 2015. Implementasi Model Pendekatan Taktik dan Teknik dalam Pembelajaran Permainan Bola Voli pada Pendidikan Jasmani Siswa Sekolah Menengah Pertama. ATIKAN, 5(1). 